\title{
Pemberian ko-kemoterapi Fraksi Etil Asetat Akar Pasak Bumi (Eurycoma Longifolia Jack) Terhadap Ekspresi Protein Ki-67 pada Tikus Model Kanker Payudara yang diinduksi DMBA
}

\author{
Suhrah Febrina Karim ${ }^{1}$, Laela Hayu Nurani ${ }^{1}$, Sitarina Widyarini ${ }^{2}$ \\ ${ }^{1}$ Program Studi Pascasarjana Farmasi, Universitas Ahmad Dahlan Yogyakarta \\ ${ }^{2}$ Program Studi Kedokteran Hewan, Universitas Gadjah Mada, Yogyakarta \\ *Email korespondensi: suhrahfebrina@ymail.com
}

\begin{abstract}
ABSTRAK
Kanker payudara dapat terjadi karena paparan dari senyawa 7,12-dimethylbenz (a) antrasene (DMBA) yang bersifat mutagenik dan karsinogenik. Tujuan penelitian ini adalah untuk menelusuri mekanisme ko-kemoterapi akar pasak bumi dan Doxorubicin terhadap aktivitas proliferasi protein Ki-67 pada Tikus SD yang diinduksi DMBA. Akar pasak bumi (Eurycoma longifolia Jack) diekstraksi menggunakan pelarut etanol $70 \%$ dan difraksinasi menggunakan etil asetat. Fraksi etil asetat akar pasak bumi diuji mekanisme molekulernya secara in vivo terhadap 5 Kelompok tikus galur Sprague Dawley terdiri atas Kelompok 1 hanya diberi pakan dan minum, Kelompok 2 diberikan DMBA dosis $20 \mathrm{mg} / \mathrm{kgBB}$, Kelompok 3 diberikan DMBA $20 \mathrm{mg} / \mathrm{kgBB}$ + Doxorubicin 1,17 mg/kgBB, Kelompok 4 diberikan DMBA $20 \mathrm{mg} / \mathrm{kgBB}$ + fraksi etil asetat akar pasak bumi $100 \mathrm{mg} / \mathrm{kgBB}$, Kelompok 5 diberikan DMBA $20 \mathrm{mg} / \mathrm{kgBB}$ + Doxorubicin $1,17 \mathrm{mg} / \mathrm{kgBB}$ + fraksi etil asetat akar pasak bumi $100 \mathrm{mg} / \mathrm{kgBB}$ kemudian dilakukan pembedahan dan uji imunohistokimia analisis data Kolmogorof Smirnof, uji Levene dan uji Kruskal Wallis. Hasil nilai rata-rata \% ekspresi protein Ki-67 juga terjadi penurunan pada kelompok ko-kemoterapi DMBA+Doxorubicin+APB $(8,89 \pm 3,20) \%$ dibandingkan kelompok DMBA+Doxorubicin $(12,73 \pm 3,37) \%$ dan kelompok DMBA+APB $(11,37 \pm 5,16) \%$, dan terdapat perbedaan yang bermakna dengan kelompok DMBA+Doxorubicin dengan nilai signifikansi 0,020 $(\mathrm{p}<0,05)$ namun tidak berdeda bermakna dengan DMBA+APB dengan nilai signifikansi 0,114 $(\mathrm{p}<0,05)$. Kesimpulan dari penelitian ini adalah pemberian ko-kemoterapi fraksi etil asetat akar pasak bumi dapat menurunkan ekpresi protein Ki-67 pada tikus model kanker payudara yang diinduksi DMBA.
\end{abstract}

Kata Kunci: Akar pasak bumi (Eurycoma longifolia Jack), ko-kemoterapi, protein Ki-67, Doxorubicin

DOI: https://doi.org/10.25026/jsk.v2i1.94

\section{PENDAHULUAN}

Menurut data GLOBOCAN (IARC) tahun 2012 diketahui bahwa kanker payudara merupakan penyakit kanker dengan persentase kasus baru (setelah dikontrol oleh umur) tertinggi, yaitu sebesar $43,3 \%$, dan persentase kematian (setelah dikontrol oleh umur) akibat kanker payudara sebesar 12,9 (Anonim, 2015). Terjadinya kanker disebabkan oleh faktor internal dan eksternal tubuh. Penyakit ini muncul oleh karena gen yang berperan dalam siklus sel tidak bekerja sebagaimana mestinya akibat adanya mutasi gen senyawa karsinogen yang banyak digunakan sebagai model dalam 
berbagai penelitian kanker adalah 7,2dimetylbenz(a)antrasene

(DMBA)

(Singletary et al., 2003). Senyawa ini dapat menyebabkan kerusakan DNA yang ditandai dengan kesalahan pengkodean gen-gen pengatur pertumbuhan. Sitokrom P450 1B1 (CYP1B1) mengaktivasi DMBA untuk membentuk DMBA-3,4diol-1,2-epoksida yang bersifat karsinogenik (Motoyama et al, 2008).

Senyawa

dimetylbenz( $\alpha$ )antrasene (DMBA) akan memicu aktivasi RAS yang akan meningkatkan proliferasi dan menghambat apoptosis. Jalur RAS/MAPK memicu aktivasi protein COX-2 dan akan menginduksi pembentukan PGE2 dari asam arakidonat yang kemudian merangsang kembali jalur RAS/MAPK yang mengakibatkan peningkatan proliferasi yang ditandai dengan meningkatnya ekspresi protein $\mathrm{Ki}-67$ (Gandamihardja et al, 2010).

Strategi yang tersedia untuk mengobati kanker payudara, dapat dilakukan dengan operasi, terapi radiasi, dan kemoterapi (terapi dengan obatobatan), contohnya Doxorubicin yang banyak digunakan dalam pengobatan kanker. Meskipun demikian ternyata penggunaan agen kemoterapi sistemik bukan saja tidak begitu efektif namun juga tidak selektif dan sangat toksik bagi jaringan lain yang normal (Istighfari et al, 2009). Dengan toksisitasnya yang tinggi maka diperlukan penelitian ko-kemoterapi dalam hal ini digunakan akar pasak bumi.

Akar pasak bumi diteliti sebagai potensial agen antikanker terhadap kanker payudara, kandungan yang dimiliki akar pasak bumi antara lain kuasinoid, alkaloid dan flavonoid (Nurani et al, 2010). Berdasarkan penelitian yang dilakukan oleh Tee et al, (2005) menyatakan bahwa akar pasak bumi mempunyai aktivitas antiproliferatif terhadap sel kanker MCF7. Protein yang terlibat pada proliferasi sel yaitu protein Ki-67. Akar pasak bumi telah diketahui memiliki aktivitas antikanker, sehingga perlu dilakukan penelusuran mekanismenya. Tujuan penelitian ini adalah untuk menelusuri mekanisme molekuler dari kombinasi akar pasak bumi dan Doxorubicin terhadap hewan uji model kanker dengan melihat aktivitas proliferasi protein Ki-67.

\section{BAHAN DAN METODE}

Bahan

Bahan yang akan digunakan adalah akar pasak bumi, CMC Na 0,5\%, corn oil (Superindo 365), 7,12 dimetylbenz(a)antrasene (DMBA) 20 $\mathrm{mg} / \mathrm{KgBB} \quad$ (SIGMA Aldrich), Doxorubicin (OGB Sanbe $2 \mathrm{mg} / \mathrm{ml}$ ), etanol 70\% (Genera Labora), formaldehid $10 \%, \mathrm{NaCl}$ fisiologis. Hewan uji yang akan digunakan pada penelitian ini adalah tikus betina galur Sprague Dawley $(S D)$ dengan berat badan 100- 200 gram dan berumur 2 bulan (Kubatka et al, 2002).

\section{Pengumpulan Bahan}

Akar pasak bumi diperoleh dari Martapura, Kalimantan Selatan kemudian dibuat serbuk dan dikeringkan di Laboratorium Teknologi Sediaan Farmasi UAD.

\section{Ekstraksi akar pasak bumi}

Serbuk dengan ukuran mesh 20/40 sebanyak $5 \mathrm{~kg}$, dilakukan maserasi dengan etanol $70 \%$ menggunakan pengaduk elektrik, maserasi dilakukan selama 3 jam, kemudian didiamkan selama 24 jam. Setelah itu disaring hingga diperoleh filtrat dan rendemen. Filtrat kemudian disimpan, sedangkan rendemen yang ada dimaserasi kembali (remaserasi) sebanyak 1 kali. Filtrat yang ada dikumpulkan dan diuapkan menggunakan rotary evaporator kemudian diuapkan di atas waterbath pada suhu $70^{\circ} \mathrm{C}$ sampai diperoleh ekstrak kental.

\section{Pembuatan Fraksi Etil asetat}

Sebanyak 50 gram ekstrak etanol (ekstrak yang paling aktif) difraksi menggunakan $20 \mathrm{~mL}$ etil asetat dan 
dilakukan dengan cara enap tuang sebanyak 5 kali. Fraksinasi dilakukan sampai senyawa yang harus masuk ke dalam etil asetat tersari semua yang ditunjukkan oleh hasil KLT yang terlihat terpisah antara fraksi larut etil asetat dan tak larut etil asetat. Fraksi kemudian dipekatkan sehingga diperoleh fraksi larut etil asetat dan tak larut etil asetat (Nurani, 2011).

\section{Pembuatan Larutan karsinogen 7,12- dimetylbenz(a)antrasene (DMBA)}

Menurut Susilowati (2004) larutan karsinogen DMBA dapat dibuat dengan pelarut minyak jagung (Corn Oil). Larutan DMBA kemudian dipejankan secara peroral pada hewan uji dengan dosis 20 $\mathrm{mg} / \mathrm{kgBB}$ selama 5 minggu dengan pemberian 2 kali seminggu. Larutan DMBA dibuat dengan melarutkan sejumlah DMBA, sesuai dosis, dengan minyak jagung sampai diperoleh larutan dengan konsentrasi yang jika diberikan pada hewan uji akan mendapatkan volume pemberian antara $0,5-1,5 \mathrm{~mL}$. Larutan DMBA selalu dibuat baru, sebelum diberikan kepada hewan uji (Meiyanto et al, 2007).

\section{Pembuatan Sampel Uji}

Fraksi etil asetat ekstrak etanol akar pasak bumi dilarutkan dalam CMC-Na 0,5\%. Pembuatan CMC-Na dilakukan dengan pemanasan campuran CMC-Na dan akuades hingga $100^{\circ} \mathrm{C}$ yang disertai pengadukan menggunakan magnetic stirrer. Pelarutan fraksi etil asetat ekstrak etanol akar pasak bumi dalam CMC-Na.

\section{Pengelompokkan Hewan Uji}

Kelompok perlakuan tersebut terdiri dari Kelompok I sebagai Normal. Kelompok ini hanya diberikan makan dan minum setiap harinya; Kelompok II sebagai kontrol sakit yaitu Kelompok yang diberikan DMBA $20 \mathrm{mg} / \mathrm{kg}$ BB selama 5 minggu sebanyak $2 x$ seminggu dimulai dari minggu ke-1 sampai minggu ke-5; Kelompok III yaitu Kelompok yang diberikan DMBA $20 \mathrm{mg} / \mathrm{kg}$ BB dan Doxorubicin $1,17 \mathrm{mg} / \mathrm{kg}$ BB selama 5 minggu sebanyak $1 \mathrm{x}$ seminggu dimulai dari minggu ke-6 sampai ke-10; Kelompok IV yaitu Kelompok yang diberikan DMBA $20 \mathrm{mg} / \mathrm{kg}$ BB dan fraksi etil asetat akar pasak bumi $100 \mathrm{mg} / \mathrm{kg} \mathrm{BB}$ selama 10 minggu dimulai dari minggu ke-6 sampai minggu ke-16; Kelompok V yaitu Kelompok yang diberikan DMBA $20 \mathrm{mg} / \mathrm{kg}$ BB dan fraksi etil asetat akar pasak bumi $100 \mathrm{mg} / \mathrm{kg}$ BB selama 10 minggu dimulai dari minggu ke-6 sampai minggu ke-16 dan diberikan Doxorubicin $1,17 \mathrm{mg} / \mathrm{kg}$ BB selama 5 minggu sebanyak 1x seminggu dimulai dari minggu ke-6 sampai ke-10, setelah itu dilakukan pembedahan.

\section{Pemeriksaan Ekspresi protein Ki-67}

Penelitian ini menggunakan mouse monoclonal antibody Ki-67 (Biocare medical). Prosedur yang digunakan untuk imunohistokimia dalam penelitian ini prosedur dari Laboratorium Patologi Anatomi, RSUP Dr. Sardjito Yogyakarta. Jaringan blok parafin dipotong dengan ketebalan 3 mikron. Letakkan diatas ob glass Poly L Lysin. Letakkan obyek glass di inkubator suhu $45^{\circ} \mathrm{C}$, biarkan semalam. Jaringan blok parafin diparafinasi setelah itu cuci dengan air kran mengalir, cuci dengan aquadest. Preparat dinkubasi dengan $\mathrm{H}_{2} \mathrm{O}_{2} 3 \%$ selama 15 menit, lalu dicuci dengan air kran mengalir. Untuk collagen 1: Retrivel dengan buffer citrat $\mathrm{pH}$ didinginkan kurang lebih selama 30 menit lalu dicuci PBS 2x selama 3-5 menit. Inkubasi dengan blocking serum atau normal serum selama 15 menit, tiriskan, bersihkan tepi-tepinya. Inkubasi dengan primer antibodi COX-2 dan Ki-67 (1:100) lalu dicuci PBS 2x selama 3-5 menit. Inkubasi dengan antibodi sekunder atau trekkie universal link selama 20 menit lalu dicuci PBS 2x selama 3-5 menit. Inkubasi dengan trekkie avidin HRP selama 10 menit lalu dicuci PBS 2x selama 3-5 menit. Teteskan cromogen DAB ( 1:50), biarkan selama 2 menit lalu 
dicuci dengan air. Counterstain dengan Hematoxylin mayer 2 menit lalu dicuci dengan air. Celupkan ke Alkohol bertingkat $70 \%, 96 \%, 100 \%$, Xylol, Mounting. Ekspresi protein Ki-67 diamati menggunakan mikroskop cahaya, pada jaringan kanker payudara dianalisis secara kualitatif dengan melihat protein yang terekspresi berwarna coklat sedangkan yang tidak terekspresi berwarna ungu atau biru.

Tabel 1. Pemberian ko-kemoterapi Fraksi Etil Asetat Akar Pasak Bumi (Eurycoma Longifolia Jack) Terhadap Ekspresi Protein Ki-67 pada Tikus Model Kanker Payudara yang diinduksi DMBA.

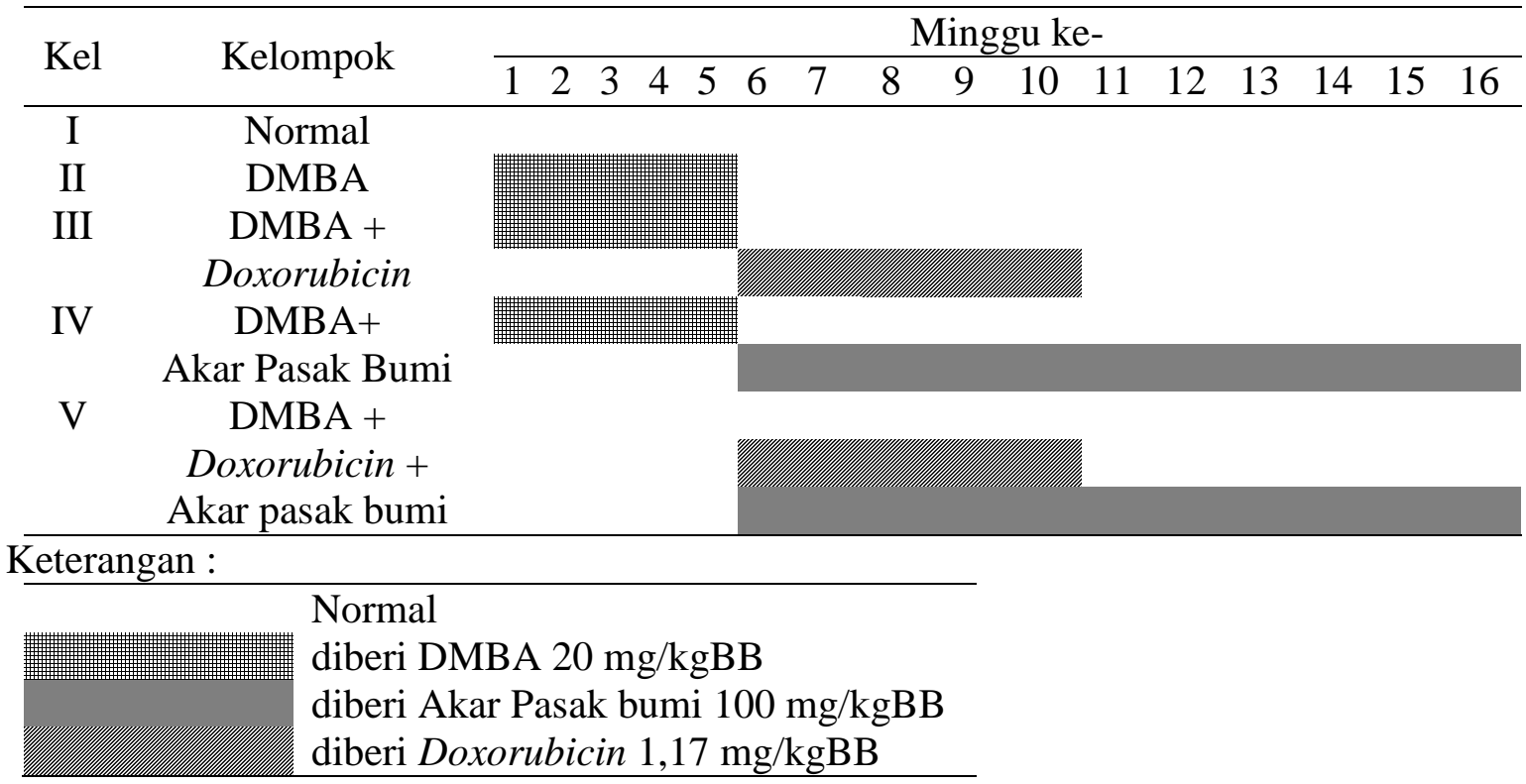

\section{Analisis data}

Data yang diperoleh dalam percobaan ini yaitu berupa jumlah sel yang terekspresi protein Ki-67, yang terekspresi berwarna coklat sedangkan yang tidak terekspresi berwarna ungu atau biru. Hasil dari data tersebut dilakukan perhitungan \% ekspresi imunohistokimia. Persen ekspresi masing-masing kelompok dianalisis secara statistik menggunakan komputer program SPSS 19 for windows.

\section{HASIL DAN PEMBAHASAN}

\section{Identifikasi Tanaman Akar Pasak Bumi}

Identifikasi tanaman perlu dilakukan untuk menghindari kesalahan dalam pengumpulan bahan dan mendapatan kebenaran identitas dari tanaman yang digunakan yaitu akar pasak bumi. Tanaman akar pasak bumi yang digunakan dalam penelitian ini diperoleh dari Martapura (Kalimantan Selatan). Identifikasi dilakukan di Laboratorium Biologi FMIPA Universitas Ahmad Dahlan Yogyakarta. Hasil menunjukkan bahwa tanaman yang digunakan dalam penelitian ini adalah benar tanaman akar pasak bumi (Eurycoma longifolia Jack).

\section{Pembuatan Fraksi Etil Asetat Ekstrak Etanol Akar Pasak Bumi}

Maserasi dilakukan dengan merendam dan mengaduk 4150 gram serbuk kering akar pasak bumi dengan pelarut etanol $70 \%$ dalam wadah maserasi. Hasil akhir didapat ekstrak etanol akar pasak bumi seberat 121,36 gram dengan ciri organoleptis berwarna coklat gelap, 
berasa pahit, kental dan tercium bau khas. Rendemen ekstrak etanol akar pasak bumi adalah sebesar $2,92 \%$.

Pertimbangan menggunakan pelarut etanol $70 \%$ karena etanol $70 \%$ bersifat semipolar, sehingga senyawa aktif akar pasak bumi yang bersifat semi polar terlarut di dalamnya (Kuo et al, 2003). Pada penelitian ini fraksinasi dilakukan dengan penambahan pelarut etil asetat yang lebih non polar dibandingkan dengan etanol untuk memperkecil komponen senyawa yang tertarik ke pelarut etil asetat. Ekstrak etanol akar pasak bumi difraksinasi dengan perbandingan 1:2,5 (etil asetat : ekstrak).

Pemilihan fraksi etil asetat sebagai pelarut berdasarkan pada penelitian-penelitian sebelumnya yang menyatakan bahwa pada sel T47D fraksi etil asetat ekstrak etanol akar pasak bumi mempunyai aktivitas sitotoksik yang lebih besar dari pada fraksi tidak larut etil asetat (Nurani, 2011).

Kromatografi Lapis Tipis (KLT) merupakan metode analisis yang digunakan untuk menganalisis secara kualitatif senyawa kandungan akar pasak bumi pada penelitian ini. Analisis senyawa pada KLT didasarkan pada nilai $\mathrm{R}_{\mathrm{f}}$ (Retention factor) dibandingkan dengan standar (Hajnos et al, 2008). Proses ini bertujuan untuk melihat kebenaran bahwa fraksi yang didapat mengandung senyawa flavonoid, kuasinoid, alkaloid. Fase diam yang digunakan dalam penelitian ini adalah silika gel $\mathrm{F}_{254}$ sedangkan fase geraknya adalah $\mathrm{CHCl}_{3}$ : Metanol (4:1) (Arifah et al, 2014). Hasil KLT menunjukkan sampel berfluoresensi biru pada UV $254 \mathrm{~nm}$ dan berfluoresensi kuning pada UV 366 nm. Ekstrak akar pasak bumi lebih banyak bercak yang ditimbulkan dibandingkan fraksi etil asetat, hal ini dikarena pelarut etanol merupakan pelarut semipolar yang dapat menyari banyak senyawa sehingga dilakukan proses fraksinasi agar senyawa yang tersari lebih spesifik. Didapatkan hasil sampel memiliki nilai $R_{f}$ yaitu 0,55 .

\section{Uji aktivitas ko-kemoterapi fraksi etil asetat ekstrak etanol akar pasak bumi}

Tikus betina galur Sprague Dawley (SD) digunakan sebagai hewan uji pada penelitian ini, pemilihan tikus Sprague Dawley dikarenakan lebih sensitif dibandingkan galur Wistar yang dapat menimbulkan kanker dalam rentang waktu yang lebih cepat (Kubatka et al., 2002). Senyawa 7,12dimetylbenz(a)antrasene (DMBA) merupakan agen karsinogen spesifik yang digunakan pada penelitian ini untuk memicu terjadinya kanker payudara, metabolit aktif DMBA yaitu DMBA-3,4diol, metabolit ini nantinya dioksidasi oleh CYP1A1 atau CYP1B1 menjadi metabolit ultimate carcinogenic (DMBA-3,4-diol1,2 epoxide). Enzim CYPIAI dan CYPIBI ini diekspresikan baik dalam hati dan payudara dimana kedua enzim ini dapat diinduksi oleh DMBA (King, 2000). Dosis senyawa 7,12-dimetylbenz(a)antrasene (DMBA) yang digunakan adalah 20 $\mathrm{mg} / \mathrm{kgBB}$ (Meiyanto, 2007) selama 5 minggu pemberian seminggu 2 kali. Penggunaan minyak jagung pada pemberian DMBA yaitu sebagai pelarut DMBA, sehingga DMBA akan lebih mudah diberikan pada hewan uji secara oral. Agen kemoterapi yang digunakan untuk terapi kanker payudara yaitu Doxorubicin, namun mekanisme aksi Doxorubicin tidak selektif terhadap sel kanker, sehingga obat ini juga bersifat toksik pada sel normal (Smith et al, 2006).

Akar pasak bumi dapat digunakan sebagai ko-kemoterapi pada kanker payudara yang menggunakan kemoterapi Doxorubicin. Berdasarkan penelitian Varghese et al (2012) mengatakan bahwa akar pasak bumi memiliki khasiat sebagai antioksidan dan antiproliferasi pada sel kanker. Senyawa yang berperan dalam efek protektif tersebut adalah kuasinoid berupa eurikomanon. Eurikomanon tersusun oleh triterpenoid yang mampu mengaktivasi sekresi membran mukosa dan melindungi lambung. Gugus hidroksil dan posisi $\mathrm{C}_{3}$ pada triterpenoid diketahui 
mampu memberikan efek perlindungan pada organ (Junior et al, 2012). Selain eurikomanon (kuasinoid), akar pasak bumi juga mengandung flavonoid dan alkaloid (Tran et al, 2014).

\section{Ekspresi Ki-67}

Untuk mengetahui tingkat proliferasi dari kanker payudara yaitu dengan pewarnaan protein Ki-67. Protein Ki-67 adalah protein non histone yang ditemukan di dalam inti sel yang berhubungan dengan proses proliferasi sel. Jaringan payudara yang sehat mengekspresikan protein Ki-67 dalam level yang rendah $(<3 \%)$. Beberapa peneliti melaporkan bahwa ekspresi reseptor steroid dan protein $\mathrm{Ki}-67$ terdeteksi pada populasi sel yang berbeda pada epitel payudara manusia yang normal, dengan ekspresi protein Ki-67 secara eksklusif hanya pada sel dengan estrogen reseptor negatif (ER). Pada karsinoma duktal in situ (DCIS), sekitar $40 \%$ dari sel tumor mengekspresikan protein Ki-67 pada kadar yang tinggi.

Berdasarkan gambar 1 terlihat bahwa adanya perbandingan antara Kelompok perlakuan yaitu adanya perbedaan warna coklat dan biru muda atau ungu. Kelompok normal pada gambar 1.a menunjukkan perbedaan warna yaitu adanya warna coklat namun tidak sebanding dengan warna ungu atau biru muda, hal ini menunjukkan bahwa tikus pada Kelompok normal mengekspresikan protein Ki-67 namun tidak banyak. Jaringan payudara yang sehat mengekspresikan Ki-67 dalam level yang rendah (<3\%) (Yerushalmi et al, 2010). Ekspresi protein Ki-67 diamati setelah 16 minggu pemberian DMBA, Doxorubicin dan fraksi etil asetat akar pasak bumi menggunakan mikroskop dengan pembesaran 400x yang dilengkapi optilab. Gambaran sel yang mengekspresikan protein $\mathrm{Ki}-67$ terlihat pada inti sel dari epitel jaringan payudara tikus, dapat dilihat pada gambar 10 .

Pada gambar 1 terlihat bahwa adanya perbandingan antara setiap kelompok yaitu adanya perbedaan warna coklat dan biru muda atau ungu. Pada gambar 1.a menunjukkan bahwa tikus pada kelompok normal mengekspresikan protein Ki-67 namun tidak banyak. Hasil perlakuan kelompok DMBA pada gambar 1.b menunjukkan bahwa ekspresi protein Ki-67 meningkat. Kelompok DMBA dan Doxorubicin pada gambar 1 . c mengekspresikan protein $\mathrm{Ki}-67$ tetapi tidak sebanyak pada kelompok DMBA. Pada Kelompok DMBA dan akar pasak bumi terlihat seperti pada gambar 1.d bila dibandingkan dengan gambar 1.b yaitu DMBA menunjukkan adanya penurunan ekspresi Ki-67. sedangkan Kelompok DMBA, Doxorubicin dan akar pasak bumi pada gambar 1.e juga menunjukkan penurunan protein Ki-67.

Setelah pengamatan menggunakan mikroskop 400x yang dilengkapi optilab kemudian dari data tersebut dilakukan perhitungan $\%$ ekspresi imunohistokimia. Hasil persentase ekspresi protein Ki-67 pada masing-masing kelompok dilakukan uji statistik. Analisis data diawali dengan uji normalitas dan uji homogenitas dengan taraf kepercayaan 95\%. Uji normalitas digunakan Kolmogorov Smirnov, sedangkan uji homogenitas digunakan Levene test. Tujuan dari dua uji tersebut adalah untuk mengetahui data yang diperoleh terdistribusi normal atau tidak dan untuk mengetahui data tersebut jomogen atau tidak. Apabila data-data tersebut terdistribusi normal dan homogen langkah selanjutnya dianalisis dengan metode statistik parametrik dengan menggunakan uji ANOVA. Namun jika tidak terdistribusi secara normal atau tidak homogen langkah berikutnya adalah data dianalisis dengan menggunakan metode statistik non parametrik dengan uji Kruskal-Walis dan uji Mann Whitney. 

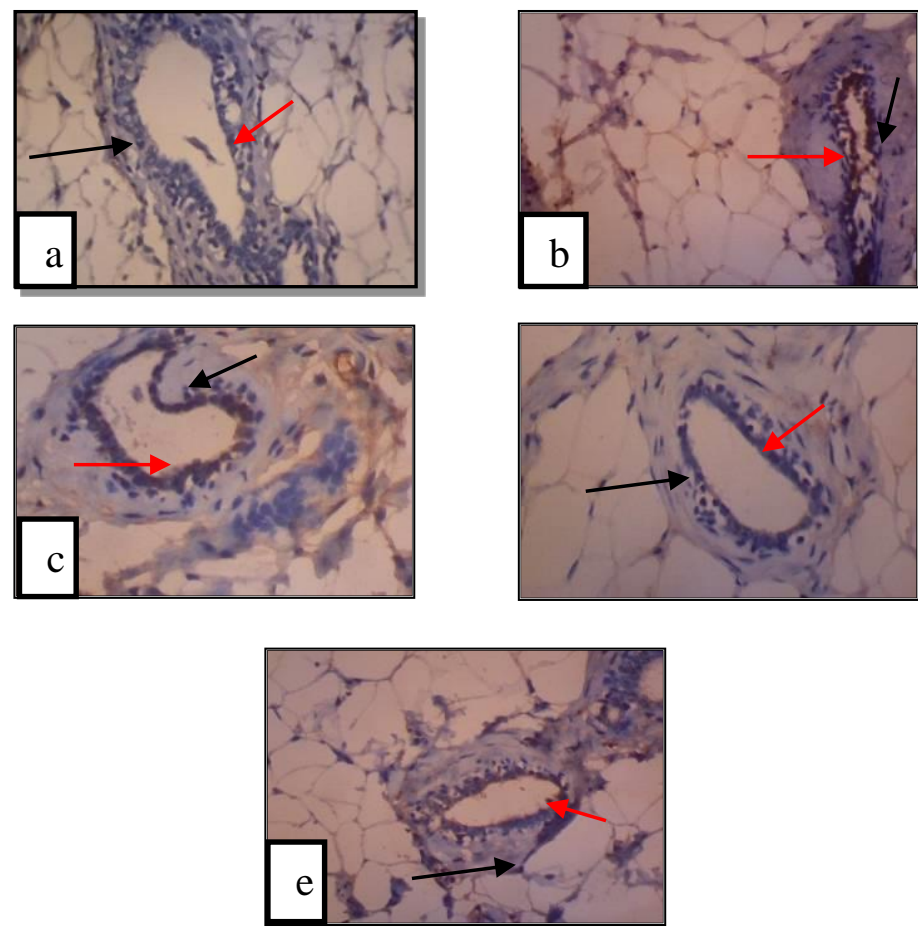

Gambar 1. Foto mikroskopis hasil perbesaran 400x uji imunohistokimia Ki-67 (a) Kontrol sehat (b) Kelompok DMBA $20 \mathrm{mg} / \mathrm{kg}$ BB (c) Kelompok DMBA $20 \mathrm{mg} / \mathrm{kg}$ BB+Doxorubicin 1,17 mg.kg BB (d) Kelompok DMBA $20 \mathrm{mg} / \mathrm{kg}$ BB+APB 100 mg.kg BB (e) DMBA 20 mg/kg BB+Doxorubicin 1,17 mg/kg BB+ APB 100 $\mathrm{mg} / \mathrm{kg} \mathrm{BB}$.

Tabel 2. Hasil pengamatan rata-rata persentase ekspresi protein $\mathrm{Ki}-67$ pada tikus model kanker payudara yang diinduksi DMBA \pm SD

\begin{tabular}{cc}
\hline Kelompok & Rata-Rata Persen Ekspresi Protein Ki-67 (\%) \pm \\
& $\mathrm{SD}, \mathrm{n}=4$ \\
\hline Normal & $4,08 \pm 1,24$ \\
DMBA & $38,87 \pm 8,19$ \\
DMBA+Doxo & $12,73 \pm 3,37$ \\
DMBA+APB & $11,37 \pm 5,16^{\mathrm{b}}$ \\
DMBA+Doxo+APB & $8,89 \pm 3,20^{\mathrm{a}}$ \\
\hline
\end{tabular}

Keterangan : $\mathrm{a}=$ terjadi perbedaan yang bermakna terhadap kelompok DMBA+Doxo $(\mathrm{p}<0,05)$

$\mathrm{b}=$ tidak terjadi perbedaan yang bermakna terhadap kelompok DMBA+Doxo $(\mathrm{p}<0,05)$

Data persentase ekspresi Ki-67 yang dianalisis menunjukkan data tidak terdistribusi normal dan tidak homogen dengan nilai signifikan 0,007 dan 0,000 $(\mathrm{p}<0,05)$. Oleh karena itu, uji selanjutnya adalah uji Kruskal-Walis dan diperoleh nilai signifikan $0,000(\mathrm{p}<0,05)$. Rata-rata persentase hasil ekspresi protein $\mathrm{Ki}-67$ pada tikus SD yang diinduksi DMBA terlihat pada Tabel 3 .

Persentase ekspresi protein $\mathrm{Ki}-67$ kelompok normal $(4,08 \pm 1,24) \%$, kelompok presentase yang diperoleh terlihat pada tabel 3 tidak sebanding dengan kelompok perlakuan lainnnya, karena pada kelompok normal tidak diberikan perlakuan hanya diberikan 
makan dan minum, sehingga tidak menunjukkan perubahan dan stabil.

Persentase ekspresi protein $\mathrm{Ki}-67$ Kelompok DMBA $20 \mathrm{mg} / \mathrm{kgBB}$ sebesar $(38,87 \pm 8,19) \%$. Hasil persentase tersebut menunjukkan perbedaan yang bermakna dengan signifikansi $0,000 \quad(\mathrm{p}<0,05)$ dengan kelompok normal $(4,08 \pm 1,24) \%$. Kelompok DMBA menunjukkan bahwa ekspresi protein Ki-67 meningkat. Senyawa DMBA meningkatkan konsentrasi $\mathrm{Ca}^{+}{ }^{+}$intraseluler, fragmentasi DNA, yang diikuti kematian sel (Burchiel et al. 1993). Peningkatan $\mathrm{Ca} 2^{+}$intraseluler dikaitkan dengan gangguan DMBA pada perambatan sinyal $\mathrm{Ca}^{+}$antar membran. Senyawa DMBA juga akan meningkatkan aktivitas reseptor sel-T yang terkait keluarga kinase Fyn dan Lck sebesar dua kali lipat. Fyn kinase diperkirakan akan merangsang fosfolirase tirosin dari fosfolipase C gamma 1 (Archuleta, 1993). Fosfolirase tirosin diketahui memiliki efek merangsang proliferasi (pembelahan) sel (Lewis 2003).

Hakkak et al, (2005) melaporkan bahwa agar bersifat aktif, DMBA (sebagai prokarsinogen) diubah oleh sitokrom $\mathrm{p}$ 450 menjadi metabolit reaktif, dihidrodiolepoksida. Metabolit ini bisa berikatan dengan DNA dan menyebabkan mutasi. Enzim CYP (cyclophilin) seperti CYP1A1 dan CYP1B1 di jaringan periferal (seperti jaringan payudara) dan CPY1A2 hati merupakan enzim yang mengkatalisis reaksi ini.

Hasil persentase yang diperoleh dari ekspresi protein Ki-67 pada Kelompok DMBA $20 \mathrm{mg} / \mathrm{kgBB}$ + Doxorubicin 1,17 $\mathrm{mg} / \mathrm{kgBB}$ sebesar $(12,73 \pm 3,37) \%$ dibandingkan dengan kelompok DMBA $20 \mathrm{mg} / \mathrm{kgBB}$ sebesar $(38,87 \pm 8,19) \%$ menunjukkan bahwa protein Ki-67 mengalami penurunan dan terdapat perbedaan yang bermakna dengan nilai signifikansi 0,000 $(\mathrm{p}<0,05)$. Hal ini terjadi disebabkan karena Doxorubicin bertindak menginterkalasi pasangan basa tertentu pada DNA sel kanker, sehingga terjadi bloking sintesis RNA atau DNA baru untuk mencegah pemotongan DNA dan pada akhirnya terjadi penggandaan DNA. Sel normal yang berproliferasi juga sebagai target dari Doxorubicin melalui hambatan ekspresi KI-67, sehingga kadang terjadi efek samping seperti myelosupresi, alopeksia atau mukositis (Aschenbrenner et al, 2009)

Hasil penelitian juga menunjukkan adanya perbedaan bermakna dari kelompok DMBA $20 \mathrm{mg} / \mathrm{kgBB}$ + APB $100 \mathrm{mg} / \mathrm{kgBB}$ sebesar $(11,37 \pm 5,16) \%$ jika dibandingkan dengan kelompok DMBA $20 \quad \mathrm{mg} / \mathrm{kgBB}$ sebesar $(38,87 \pm 8,19) \%$ dengan nilai signifikansi $0,000 \quad(p<0,05)$. Aktivitas zat aktif kuarsinoid akar pasak bumi sebagai antikanker diduga melalui penghambatan ekspresi Ki-67 dengan melibatkan enzimenzim antioksidan dan respon imun seluler (Tee et al, 2010), sedangkan hasil persentase ekspresi protein Ki-67 pada kelompok ko-kemoterapi DMBA 20 $\mathrm{mg} / \mathrm{kgBB}+$ Doxorubicin $1,17 \mathrm{mg} / \mathrm{kgBB}+$ APB $100 \mathrm{mg} / \mathrm{kgBB}$ sebesar $(6,42 \pm 1,88) \%$ jika dibandingakn dengan kelompok DMBA $20 \mathrm{mg} / \mathrm{kgBB}+$ Doxorubicin 1,17 $\mathrm{mg} / \mathrm{kgBB}$ sebesar $(8,89 \pm 3,20) \%$ menunjukkan bahwa protein Ki-67 mengalami penurunan dan terdapat perbedaan yang bermakna dengan nilai signifikansi $0,020 \quad(\mathrm{p}<0,05)$. Fraksi etil asetat akar pasak bumi dalam mekanisme antikankernya melalui pemacuan perbaikan DNA yang rusak karena efek samping Doxorubicin. Akar pasak bumi dapat digunakan sebagai ko-kemoterapi pada kanker payudara yang menggunakan kemoterapi Doxorubicin, hal ini karena akar pasak bumi memiliki senyawa bioaktivitas kuasinoid, alkaloid dan flavonoid (Nurani, 2010).

Berdasarkan penelitian Varghese et al (2012) mengatakan bahwa akar pasak bumi memiliki khasiat sebagai antioksidan dan antiproliferasi pada sel kanker. Senyawa yang berperan dalam efek protektif tersebut adalah kuasinoid berupa eurikomanon. Eurikomanon tersusun oleh triterpenoid yang mampu 
mengaktivasi sekresi membran mukosa dan melindungi lambung. Gugus hidroksil dan posisi $\mathrm{C}_{3}$ pada triterpenoid diketahui mampu memberikan efek perlindungan pada organ (Junior et al, 2012). Selain eurikomanon (kuasinoid), akar pasak bumi juga mengandung flavonoid dan alkaloid (Tran et al, 2014).

\section{KESIMPULAN}

Dari hasil penelitian yang telah dilakukan, dapat disimpulkan bahwa kokemoterapi fraksi etil asetat akar pasak bumi (Eurycoma longifolia Jack) dengan dosis $100 \mathrm{mg} / \mathrm{KgBB}$ dan Doxorubicin $1,12 \mathrm{mg} / \mathrm{KgBB}$ dapat menghambat proliferasi protein Ki-67 pada tikus Sprague Dawley yang diinduksi DMBA.

\section{UCAPAN TERIMA KASIH}

Penulis mengucapkan banyak terimakasih kepada Dikti Hibah Tim Pascasarjana TA 2015/1016 yang telah banyak memberikan bantuan terhadap penelitian ini. Penulis juga mengucapkan terima kasih kepada pihak-pihak yang memberikan dukungan hingga penelitian ini dapat terselesaikan.

\section{DAFTAR PUSTAKA}

[1]. Anonim., 2015, diakses tanggal 30 oktober 2015 http://www.depkes.go.id/downloa d.php?file=download/pusdatin/bul etin/buletin-kanker.pdf.

[2]. Arifah, A. N., dan Nurkhasanah, 2014, Efek Fraksi Etil Asetat Ekstrak Etanol Akar Pasak Bumi (Eurycoma longifolia, Jack) terhadap Aktivitas Fagositosisi Makrofag secara In Vitro, Pharmaçiana, Vol (4) No.1: 9-1.

[3]. Gandamihardja. S, Firman F. W, Shahib, N, 2012, Peran Siklooksigenase dalam Pertumbuhan Kanker Leher Rahim, Skripsi, Universitas Indonesia.
[4]. Hajnos, M. W., Sherma, J., and Kowalska, T., 2008, Thin Layer Chromatography in Phytochemistry, vol 99, p 5-9, CRC Press, London New York.

[5]. Hatim, N.B., 2012, Aktivitas Antikanker Ekstrak Etanol Daun Surian (Toona sinensis) pada Tikus Betina Sprague Dawley yang Diinduksi 7,12DimetilBenz(a)antrasena, Skripsi, Fakultas Matematika dan Ilmu Pengetahuan Alam Institut Pertanian Bogor, Bogor.

[6]. Hollander, M. C., Kovalsky, O., Salvador, J. M., Kim, K. E., Patterson, A. D., Haines, D. C., et al, 2001, DimetilBenz(a)antrasena Carcinogenesis in Gadd45a-null Mice Is Associated with Decreased DNA Repair and Increased Mutation Frequency, Cancer Research 61, 2487-2491.

[7]. Istighfari, R., Meiyanto, E, 2009, Aplikasi Ko-Kemoterapi Fraksi Etil Asetat Ekstrak Etanolik Daun Sambung Nyawa (Gynura Procumbens (Lour). Merr) Pada sel Kanker Payudara Mcf-7 , Majalah Ilmu kefarmasian, Vol. VI, No, 132-141

[8]. Junior, L.C.K., Jose, R.S., Rivaldo, N., Sergio, F.A., and Valdir, C.F., 2012, The therapeutic lead potential of metabolites obtained from natural sources for the treatment of peptic ulcer, Phytochem Rev, 1-50.

[9]. Kubatka, P., Ahlersova E., Ahlers I, Bojkova B., Kalicka K., Adamnekova E., Markova M., Chamilova M., and Cermakova M., 2002., Variability of Mammary arcinogenesis Induction in Female Sprague-Dawley and Wistar; Hans Rats; the Effect of Seasons, Physiology Research, 51, 663-640. 
[10]. Kuo, P., C., Damu, A., G., Lee, K., H., Wu, T., S., 2004, Cytotoxic and antimalarial constituents from the roots of Eurycoma longifolia, Bioorg. Med. Chem, 12: 537-544

[11]. Meiyanto, E., Susilowati, S., Tasminatun, S., Murwanti, R., and Sugiyanto. 2007. Efek Kemopreventif ekstrak etanolik Gynura procumbens (Lour), Merr pada karsinogenesis kanker payudara tikus. Majalah Farmasi Indonesia 18: 154-161.

[12]. Motoyama Jun, Noriyuki Yamashita, Tomio Morino, Masashi Tanaka,Takeshi Kobayashi and Hiroyuki Honda, 2008, Hyperthermic treatment of DMBA-induced rat mammary cancer using magnetic nanoparticles. Bio Magnetic Research and Technology., 6:2

[13]. Nurani, L. H. 2011. Mekanisme molekuler kemopreventif dan antikanker senyawa aktif akar pasak bumi (Eurycoma longifolia Jack) kajian in vitro pada sel T47D dan in vivo pada kanker payudara pada tikus SD yang diinduksi DMBA. Disertasi, Universitas Gadjah Mada.

[14]. Puji, R. W. Achmad, R. Ekowati, H. 2012. Aktivitas Antiproliferatif Jintan Hitam Nigell Sativa) Pada Sel Paru Tikus Yang Diinduksi 7,12-Dimetilbenz-A]Antrasena (Dmba), Makara, Kesehatan, Purwokerto.

[15]. Singletary, K.W., Stansbury, M.J., Giusti, M., 2003, Inhibition of Rat Mammary Tumorigenesis by Concord Grape, J. Agric. Food Chem. , 51, 7280-7286.

[16]. Smith, L., M. B. Watson, S. L. O'Kane, et al., 2006, The analysis of Doxorubicin resistance in human breast cancer cells using antibody microarrays, Molecular Cancer Therapeutics,5(8): 21152125.

[17]. Susilowati, S., 2004, Efek Kemopreventif Ekstrak Etanolik Daun Gynura procumbens (Lour, Merr terhadap Kanker Payudara Tikus yang Diinduksi DimetilBenz(a)antrasena (DMBA), Thesis, Fakultas Pasca Sarjana Universitas Gadjah Mada, Yogyakarta.

[18]. Tee, T., T., and Hawariah L., P., A., 2005, Induction of Apoptosis by Eurycoma longifolia Jack Extracts, Anticancer Research, 25 : 2205-2214.

[19]. Tee, Thiam Tsui, Azimahtol and Hawariah Lope Pihie, 2005, Induction of Apoptosis by Eurycoma longifolia Jack Extract, School of Biosciences and Biotechnology, Faculty of Science and Technology, National University of CERATA Journal Of Pharmacy Science. UKM Bangi, Selangor, Malaysia, Source Anticancer Reasearch. 25 (3B): 2205-13.

[20]. Tran, T.V.A., Clemens, M., Stefan, S., Atanas, G.A., Elke, H.H., Verena, M.D., and Hermann, S., 2014, NF-KB Inhibitors from Eurycoma longifolia Jack, Journal of Natural Products, 77: 483-488.

[21]. Varghese, C., Ambrose, C., Jin, S., Lim, Y., \& Keisaban, T. 2013. Antioxidant and antiinflammatory activity of Eurycoma longifolia Jack, a traditional medicinal plant in Malaysia. International Journal of Pharmaceutical Sciences and Nanotechnology, Volume 5. 